\title{
THE IMPACT OF BRAND EVALUATION, SATISFACTION, BRAND RELATIONSHIP AND TRUST TO BRAND LOYALTY: A CASE STUDY OF THE INDONESIAN SMARTPHONE INDUSTRY
}

\author{
Nicholas Wilson', Stanley Tulus Makmud ${ }^{2}$ \\ ${ }^{1}$ Fakultas Ilmu Sosial dan Humaniora, Universitas Bunda Mulia, Jakarta \\ Email:wp8989@yahoo.com \\ ${ }^{2}$ Business School, Universitas Pelita Harapan, Tangerang \\ Email: stley9@gmail.com
}

\begin{abstract}
This research was conducted in order to uncover the impact of brand evaluation, satisfaction, and trust on brand loyalty in the Indonesian smartphone industry. This research implemented survey method, in which questionnaires were used as the instruments to collect all of the data from the respondents. A total of 300 respondents participated in this research, in which, after further assessments, all data could be deemed as valid and reliable. All data that have been collected and assessed then were analyse used Partial Least Squares-Structural Equation Modelling (PLS-SEM) method, using Smart PLS 3.2.7 software. Based on the results of the data analysis, it could be concluded that brand evaluation, satisfaction, brand evaluation, and trust had a positive impact on brand loyalty.
\end{abstract}

Keywords : brand evaluation, satisfaction, trust, brand relationships, brand loyalty

\begin{abstract}
ABSTRAK
Penelitian ini dilakukan untuk mengungkap dampak evaluasi merek, kepuasan, dan kepercayaan terhadap loyalitas merek di industri smartphone Indonesia. Penelitian ini menerapkan metode survei, di mana kuesioner digunakan sebagai instrumen untuk mengumpulkan semua data dari responden. Sebanyak 300 responden berpartisipasi dalam penelitian ini, di mana, setelah penilaian lebih lanjut, sетиа data dapat dianggap valid dan dapat diandalkan. Semua data yang telah dikumpulkan dan dinilai kemudian dianalisis menggunakan metode Partial Least Squares-Structural Equation Modeling (PLSSEM), menggunakan perangkat lunak Smart PLS 3.2.7. Berdasarkan hasil analisis data, dapat disimpulkan bahwa evaluasi merek, kepuasan, evaluasi merek, dan kepercayaan memiliki dampak positif pada loyalitas merek.
\end{abstract}

Kata kunci: evaluasi merek, kepuasan, kepercayaan, hubungan merek, loyalitas merek

\section{RESEARCH BACKGROUND}

Loyalty had been long understood as one of the most important trait and factor which could determine to which direction companies will going to (Wilson \& Keni, 2018; Wilson, 2018). It is because without loyalty, it is almost impossible for companies to retain their customers, and considering the large number of competitors conducting their business in the same or similar industry with us, it will be easy to assume that it wouldn't take much time for the customers to shift their interests and 
THE IMPACT OF BRAND EVALUATION, SATISFACTION, BRAND RELATIONSHIP AND TRUST TO BRAN LOYALITY: A CASE STUDY OF THE INDONESIAN SMARTPHONE INDUSTRY

preferences to what our competitors are about to offer (Wilson, 2018). Such a problem would be more damaging for companies which conducted their business in the industries which had a very large number of competitors which make it impossible to determine how many companies are conducting their business in those industries in a country. And, one of those industry is the Food and Beverages (F\&B) industry. Characterized by it's relatively low barrier to entry, low to moderate costs of investment, growing market potential and large number of potential customers, a lot of people had been investing their money in such a lucrative and booming industry which saw the number of entrepreneur conducting business in this industry to escalate annually. On the other hand, Smartphone industry was also long understood and considered to be one of the fastest growing industry in the world, despite it's highbarrier to entry and relatively high investment costs. Despite there's only been several companies establishing their presence in this industry (such as Apple, Samsung, Oppo, Vivo, Xiaomi, Realme, etc), however, the development of this industry (particularly in the Asian region) is growing rapidly thanks to the large amount of customers (or potential customers) whose appetite of owning a new phone (or a newer-generation of smartphone) seems to have no end.

Furthermore, such a trend could be seen more clearly in Southeast Asia countries, especially in Indonesia, in which smartphone industry had been consistently topped the ranking as one of the fastest growing industry in the country, along with F\&B industry and hospitality industry. Moreover, as one of the largest and mostpopulous country in the world, many companies had seen Indonesia as an incredibly large countries full of market potential which will allow the smartphone industry to sustain itself and flourish, particularly in the low-to-middle market sectors, where affordable-yet-technologically advanced smartphone seems to successfully penetrate the market full of customers (and buyer) from sectors. Several Chinese smartphone companies, such as OPPO, VIVO, RealMe, and Xiaomi are even be able to successfully challenge the Apple and Samsung duopoly in the Indonesian smartphone industry by releasing and producing a more affordable (less costly) smartphone which could be accessed and bought by those who were categorized or grouped as the lower to middle income customers. In the other hand, both Apple and Samsung seems to experience such a difficulty in penetrating the same markets since both companies had been long understood and known to be producing and releasing smartphones aiming at the middle to high income customers. Even a lot of customers from middle-to-high income segments had been shifting their preferences to purchase a new and more affordable smartphone produced by these Chinese-owned enterprises, since the smartphone that they offer had a similar performance, specifications, and quality with the one produced by both Apple and Samsung which had been known as the companies which produce high-end and state-of-the-art smartphones. Therefore, considering all of the facts and trend stated above, it would be safe and not exaggerated to state that intense competition within companies in the Indonesian smartphone industry are inevitable.

Brand evaluation, satisfaction, brand relationship, and trust had been long studied and proven as several variables or factors which had an impact on brand loyalty, either negatively or positively. Such a result then prove that the relationship between brand evaluation, satisfaction, brand relationship, trust and loyalty are a one-way 
relationships, which means that an increase in customers' satisfaction with the brand will most likely cause customers' loyalty toward the brand to increase, and vice versa. These findings indicate that it would be crucially important for marketers, practicioners, academicians, or even general people to understand the important impact of brand evaluation, satisfaction, brand relationship, and trust on customers' loyalty toward a certain brand in the Indonesian smartphone industry. Brand evaluation itself could be defined or understood as customers' self-evaluation toward a brand that he or she had just been exposed to, in which this evaluation could be both negative or positive (Velotsou, 2015). Meanwhile, satisfaction could be defined as customers' perception in regards with the quality of the product or service that was offered by a company, whether or not the quality of that service exceeded the customers expectation (Wilson \& Keni, 2018; Wilson, 2018). Furthermore, brand relationship could be defined as the emotional bond that was formed between customer and the brand itself, in which strong brand relationship between customers and the brand will most likely cause the possibility of the customers shifting their preferences to the other brand (within the same product or service category) to be minimum (Wilson, Theodorus \& Tan, 2018). Meanwhile, trust could be defined as customers' state of belief that the brand in which the customers had just been exposed to is the one that they believe won't disappoint them (Wilson \& Keni, 2018). Meanwhile, brand loyalty could be defined as customers' attitude toward the brand, in which customers won't use or buy any products or services from the other brands, other than the one that they're currently using (Wilson, 2018).

Therefore, based on the introduction and background stated above, authors would like to determine the impact of brand evaluation, satisfaction, brand relationship, and trust toward brand loyalty in the Indonesian smartphone industry.

\section{THEORETICAL FRAMEWORK AND HYPOTHESES}

\subsection{Brand}

In consumer marketing, brands can provide the primary points of differentiation between competitive offerings and such as they can be critical success of companies (Wood, 2000). The American Marketing Association define brand as a name, term, sign, symbol, design or combination of them intended to identify the goods or service of one seller or group of sellers and to differentiate them from those of competitors (Wood, 2000). Ambler (1997) define brand as the promise of the bundles of attributes that someone buys and provide satisfaction. Brands serve valuable functions. At the most basic level, brands serve as markers for the offerings of a firm (Keller \& Lehmann, 2006), Keller \& Lehmann (2006) also state that brands for customer can be to simplify choice, promise particular quality level, reduce risk.

\subsection{Brand Loyalty}

Some of the customers are believed that their personal choice of brand is better than the others (Mao, 2010). According to Oliver (2015) loyalty can be described as a deeply held commitment to rebuy a preferred product or service consistently in the 
THE IMPACT OF BRAND EVALUATION, SATISFACTION, BRAND RELATIONSHIP AND TRUST TO BRAN

LOYALITY: A CASE STUDY OF THE INDONESIAN

SMARTPHONE INDUSTRY

future, thereby causing repetitive the same brand despite situational influences and marketing efforts causing switching behavior. Brand loyalty was often measured simply only through purchase repeat in terms of behavior in the past while customer loyalty can be considered more widely rather than expressed by simple purchase behaviors (Ghorbani \& Mousavi 2014). Brand loyalty can be conceptualized as the final dimension of consumer brand resonance symbolizing the consumer's relationship and level of identification with a brand (Erdoğmuş \& Çiçek 2012). Giovanis \& Athanasopolou (2017) says that brand loyalty is considered to have two dimensions: attitudinal and behavioral loyalty. Both researchers and practitioners agreed that brand loyalty as a critical factor for firm's survival and prosperity since it contributes to increased repurchase volume and better acquisition (Giovanis, 2016).

\subsection{Brand Evaluation}

Consumers rate the brands in their minds often. Some customer evaluate the brands by using any indications. And some customer also relate the brand as a person (Gilbert \& Hewlett 2003). According to Velotsou (2015), self-generated belief that brand are developed in the minds of each consumer through controlled signaling and other uncontrollable information that the consumer received about the brand and shapes the evaluation of the brand. To evaluate a brand, we can use a brand image and brand reputation as a basis of brand evaluation. (Fombrun \& Rindova, 2000).

\subsection{Satisfaction}

Brand satisfaction has a significantly positive influence on brand loyalty (Sahin et al., 2011). A dissatisfied customer is more likely to search for information on alternatives and more likely to yield to competitor overtures than is a satisfied customer. Also, a dissatisfied customer is more likely to resist attempts by his or her current retailer to develop a closer relationship and more likely to take steps to reduce dependence on that retailer (Anderson \& Srinivasan 2003).

Measurement of customer service are very important. But there is no universally accepted method or measurement scale that exists (Gilbert \& Velotsou, 2006). The measurement of consumer behavior is more exploratory than exact science (Gilbert \& Velotsou, 2006). Ballester et al., (2005) define brand satisfaction as an overall evaluation of the entire brand.

\subsection{Brand Trust}

Brand trust is defined as feeling of security held by consumer in their interaction with the brand, that it is based on the perceptions that the brand is reliable and responsible (Taskin et al., 2016). Trust is important in many high-involvement; premium product markets because consumers are exposed to costs associated with adverse selection and moral hazard, both agency costs. Sahin et al. (2011) said that in their study brand trust have significantly positive effect on brand loyalty. 
Chaudhuri \& Holbrook (2001) says that brand trust is involving a process that is well thought out and carefully considered, while the development of brand affect is more spontaneous, more immediate, and less deliberately reasoned in nature. Meanwhile Xingyuan et al. (2010) says brand trust can be defined as consumer's disposition toward a brand characterized by positive expectation of and willingness to rely on the brand. Trust has received a great deal of attention from scholars in several disciplines such as psychology, sociology and more applied area such as marketing (Delgado et al., 2006). The brand will have a high probability to be in a positive result for the customer if the consumer trust the brand (Delgado et al., 2006). To build trust, both supplier and the buyer have to keep their promises (Velotsou, 2015).

\subsection{Brand Relationship}

When customer experience some interactions with the brand, there is an emotional relationship between them and customer aware that they create and develop the relation. Consumer brand relationship exist in various contexts, especially in welldefined groups of consumers and sub-cultures (Veloutsou, 2015). By connecting to the brand, consumers seek emotional, psychological benefits aside from material values from the brand (Aurier \& Lanauze, 2012). So the consumer treats the brand as an inactive partner and eventually developing relationship with the brand during interactions over time with the brand (Peng et al., 2014).

A long-term brand relationship likely develops when consumers believe the brand reflects their personalities and enhances their self-esteem and social status (Zhou et al., 2011). Brand attachments or relationship with the brand is the longterm bond between the consumer and the brand, and it can be distinguished from other concepts, such as brand attitudes, satisfaction, and involvement (Thompson et al., 2005 on Velotsou, 2015). Furthermore, Velotsou (2015) says the strength of brand relationship can be measured with the strength of emotional connection with the brand and the strength of intended communication with the brand.

\subsection{Previous Studies}

2.7.1 Cleopatra Veloutsou (2015) did a research regarding how brand evaluation, trust and satisfaction serve as a predictor for brand loyalty. The data were collected from 189 women who are using lipstick in Glasgow, Scotland. The hypothesis for this research was as followed.

a. Positive brand evaluation has a positive effect on brand loyalty

b. Satisfaction has a positive effect on brand loyalty

c. Trust has a positive effect on brand loyalty

Concluding the research, Veloutsou state that all corresponding variables in her research shows positive result. All the correlation values were positive, indicating loyalty did have very strong correlations with all variables (brand evaluation, satisfaction, and trust). Veloutsou also add brand relationship as one factor that affect 
THE IMPACT OF BRAND EVALUATION, SATISFACTION,

BRAND RELATIONSHIP AND TRUST TO BRAN

LOYALITY: A CASE STUDY OF THE INDONESIAN

SMARTPHONE INDUSTRY

brand loyalty. Through two dimensions from brand relationship
Nicholas Wilson dan

Stanley Tulus Makmud

2.7.2 Chaudhuri and Holbrook (2001) conduct a research regarding the effects of brand trust and brand affect to brand loyalty and indirect effects of brand trust and brand affect to the market share and market price. The hypothesis for the research conducted by Chaudhuri and Holbrook was as followed.

a. Brand trust is positively related to purchase loyalty and attitudinal loyalty

b. Brand affect is positively related to purchase loyalty and attitudinal loyalty

c. Market share increase as brand loyalty increase

d. Relative price increase as brand loyalty increase (Chaudhuri \& Holbrook, 2001)

The method conducted in this research consist of three phases ensures that connections between any two variables are not bias due to asking the same respondents to provide answers in a single questionnaire. The use of different samples in every phases help to prevent consistency bias and provide more valid result.

2.7.3 Yoon and Uysal (2005) conduct a research regarding how push and pull motivation could create motivation for traveler to go to a certain destination and how the satisfaction from traveler's decision can affect the destination loyalty. The result of this research state that push and pull motivation is considerable to increase the satisfaction of the customer and positive satisfaction affect the destination loyalty. Although this research mainly used for travel purpose, it is similar with brand product. Motivation will lead to purchase decision from the customer. When the customer have purchase the product, they will gain a certain amount of satisfaction. The higher the satisfaction, the higher the loyalty from the customer (Yoon \& Uysal, 2005). Research conducted by Mao (2010) find that customer brand loyalty plays more important role in the modern global marketing. In order to maximize the profit, companies try different marketing strategies, among which loyalty is recognized by large amount of businessmen. To find the elements and effect of loyalty, businessmen or companies may understand the customer faith toward their products or services.

2.7.4 Previous research conducted by Erdogmus \& Cicek (2012) find that advantageous campaign of social media are the most significant drivers to brand loyalty and then followed by relevancy by content, popularity of the content among friends, and appearing on different social media platforms. Customer brand loyalty also affected positively by the different platforms and applications that are offered by the brand of the social media. they also find that relevancy is the second most important factor affecting brand loyalty, therefore companies must keep themselves updated.

\subsection{Research Hypotheses}




\subsubsection{Brand Evaluation has a positive effect on Brand Loyalty}

Customers tend to be loyal to brands that they evaluate higher and have a good attitude towards, and brand reputation is one of the antecedents of brand loyalty (Gilbert \& Hawlett, 2003). Velotsou (2015) state relationship or link between brand evaluation and brand loyalty exist and is positive. Esch et al. (2006) says that the more brand is evaluated and perceived, it can be more important predictors of current purchases and eventually lead customer to brand loyalty, so there is connection or link between brand evaluation and brand loyalty. Keller \& Lehmann (2006) state that understanding the image of the corporate and reputation impact on customer purchase is one of the key question of brand research. Based on the theories above, authors would like to posit the following hypothesis:

\section{H1 : Brand Evaluation has a positive effect on Brand Loyalty}

\subsubsection{Trust has a positive effect on Brand Loyalty}

Hess \& Story (2005) state that trust is important as the connector between satisfaction and personal connection and can transforming a positive transactional orientation toward a brand into enduring and close personal and commited relationship with the brand. Trust and satisfaction can combine to provide the conditions to enduring relationship between customer and brand (Hess \& Story, 2005). Velotsou (2015) state that brand trust has a direct and positive effect on brand loyalty. Han et al. (2008) also state that trust is one of many elements to influence on customer loyalty towards brands especially after time of crisis, so trust can enhance brand loyalty. Based on the theories above, authors would like to posit the following hypothesis:

\section{H2: Trust has a positive effect on Brand Loyalty}

\subsubsection{Satisfaction has a positive effect on Brand Loyalty}

Velotsou (2015) state that the amount level of satisfaction derived from customer from experience using the product or services can be influence the bond developed between customer and the brand. Therefore satisfaction has a positive effect on brand loyalty (Velotsou, 2015). Satisfaction can be one of the element to lead customer to repurchase, likely moderated by satisfaction, relational, and marketplace characteristics (Voss et al., 2010). According to Harris \& Goode (2004), satisfaction in various context can be translates into loyalty when customer feel of satisfaction is really high. hypothesis:

Based on the theories above, authors would like to posit the following

H3: Satisfaction has a positive effect on Brand Loyalty

\subsubsection{Brand Relationship has a positive effect on Brand Loyalty}


THE IMPACT OF BRAND EVALUATION, SATISFACTION, BRAND RELATIONSHIP AND TRUST TO BRAN

LOYALITY: A CASE STUDY OF THE INDONESIAN

SMARTPHONE INDUSTRY

According to Giovanis (2016), brand relationship commitment has a direct and positive effect on brand loyalty. Velotsou (2015) state that the relationship could lead to a degree of loyalty so strength of consumer loyalty has a positive effect on brand loyalty. Too et al. (2001) says that the perception of company relationship appears to be crucial to enhance customer to become more loyal to the brand. Meanwhile Algesheimer et al. (2005) on Velotsou (2015) state that brand relationship has a positive impact to brand loyalty. Brand loyalty can offers a useful way to examine interplay between brand relationship and brand community (Algesheimer et al., 2005). Based on the theories above, authors would like to posit the following hypothesis:

H4: Brand Relationship has a positive effect on Brand Loyalty

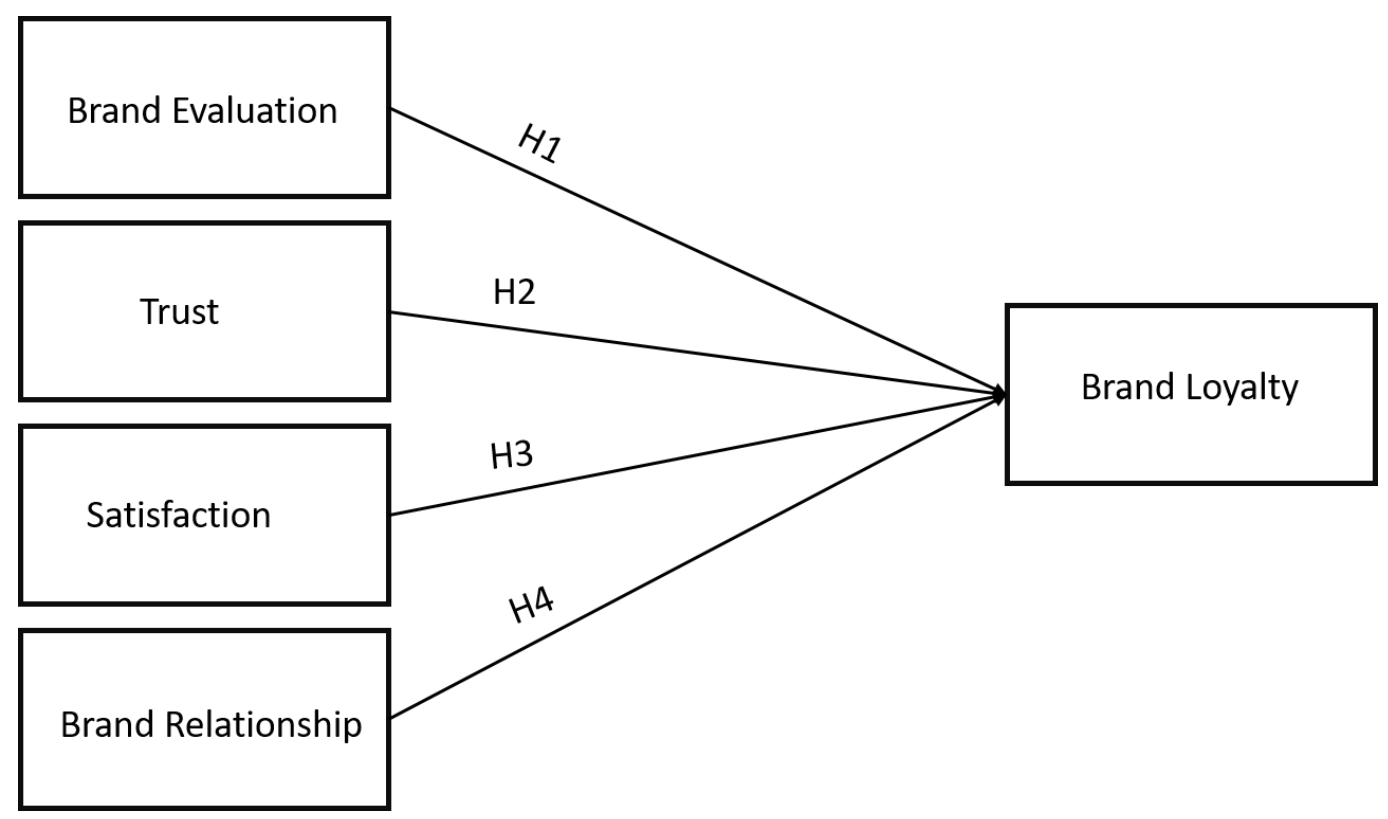

Figure 3. Research Model

\section{RESEARCH METHODOLOGY}

\subsection{Method}

This research utilized survey method, in which questionnaires were used as instruments to collect the data from the respondents. A total of 300 respondents participated in this research, in which, data gathered from the respondents will further be analyzed using Partial Least Squares-Structural Equation Modeling (PLS-SEM) 
method, in which all of the data will be processed using Smart PLS 3.2.7 statistical software. Furthermore, this research utilized purposive sampling method as the sampling technique, since only those who've ever bought and used smartphone products for the last one year were selected and chosen as the respondents.

Regarding the questionnaire used in this research, a five-points Likert scale was used to measure respondent's level of agreement regarding the statements provided in the questionnaire. Respondent's response could range from " 1 " to " 5 ", in which " 1 " stand for "strongly disagree", "2" which stand for "disagree", "3" which stand for "neutral", "4" which stand for "agree", and "5" which stand for "strongly agree." Furthermore, a total of thirty five items measuring five variables were included in the questionnaire, in which 8 items measuring variable brand loyalty were adapted from Veloutsou (2015), 5 items measuring variable brand evaluation were adapted from Veloutsou (2015), 7 items measuring variable trust were adapted from Veloutsou (2015), 4 items measuring variable satisfaction were adapted from Veloutsou (2015), and 11 items measuring variable brand relationship were also adapted from Veloutsou (2015).

\subsection{Pretest}

Before the questionnaire was used in this research, a pretest on 50 respondents was conducted in order to ensure the validity, reliability, and the clarity of the items included on the questionnaire. After the pretest was conducted, the data were gathered and analyzed to ensure it's validity and reliability. After analyzing the data, it was confirmed all items and variable had fulfilled the validity and reliability criteria. Therefore, all of the items in the questionnaire were used in the research.

\section{RESULTS AND DISCUSSIONS}

\subsection{Outer Model Analysis}

Before the data were analyzed in order to test the hypotheses, the outer model analysis was conducted in order to test that the model had fulfilled the validity and reliability criteria. The validity and reliability criteria were as follows: the factor loadings value of each items should be greater than 0.7 , the AVE value of each variable should be greater than 0.5 , the composite reliability and cronbach's alpha value of each variable should be greater than 0.7 . After assessing the model, it was revealed that the model had fulfilled all the criteria set in the outer model measurement, with the results was shown as follows. 
THE IMPACT OF BRAND EVALUATION, SATISFACTION, BRAND RELATIONSHIP AND TRUST TO BRAN LOYALITY: A CASE STUDY OF THE INDONESIAN SMARTPHONE INDUSTRY
Nicholas Wilson dan Stanley Tulus Makmud

Table 1.

Outer Model Analysis (Validity)

\begin{tabular}{|c|c|c|c|}
\hline Indicators & Variables & Loading Factor & AVE \\
\hline BE1 & \multirow{5}{*}{ Brand Evaluation } & 0.738 & \multirow{5}{*}{0.672} \\
\hline BE2 & & 0.716 & \\
\hline BE3 & & 0.730 & \\
\hline BE4 & & 0.798 & \\
\hline BE5 & & 0.752 & \\
\hline SAT1 & \multirow{4}{*}{ Satisfaction } & 0.758 & \multirow{4}{*}{0.56} \\
\hline SAT2 & & 0.824 & \\
\hline SAT3 & & 0.792 & \\
\hline SAT4 & & 0.711 & \\
\hline TR1 & \multirow{8}{*}{ Trust } & 0.786 & \multirow{8}{*}{0.549} \\
\hline TR2 & & 0.714 & \\
\hline TR3 & & 0.727 & \\
\hline TR4 & & 0.744 & \\
\hline TR5 & & 0.745 & \\
\hline TR6 & & 0.868 & \\
\hline TR7 & & 0.775 & \\
\hline TR8 & & 0.716 & \\
\hline BR1 & \multirow{11}{*}{$\begin{array}{c}\text { Brand } \\
\text { Relationship }\end{array}$} & 0.802 & \multirow[t]{11}{*}{0.673} \\
\hline BR2 & & 0.730 & \\
\hline BR3 & & 0.735 & \\
\hline BR4 & & 0.749 & \\
\hline BR5 & & 0.795 & \\
\hline BR6 & & 0.707 & \\
\hline BR7 & & 0.778 & \\
\hline $\mathrm{BR} 8$ & & 0.851 & \\
\hline BR9 & & 0.710 & \\
\hline BR10 & & 0.850 & \\
\hline BR11 & & 0.843 & \\
\hline BL1 & Brand Loyalty & 0.891 & 0.337 \\
\hline
\end{tabular}




\begin{tabular}{ll}
\cline { 2 - 2 } BL2 & 0.763 \\
BL3 & 0.764 \\
BL4 & 0.745 \\
BL5 & 0.749 \\
BL6 & 0.783 \\
BL7 & 0.833 \\
BL8 & 0.807 \\
BL9 & 0.719
\end{tabular}

Table 2.

Discriminant Validity

\begin{tabular}{lccccc}
\hline & $\begin{array}{c}\text { Brand } \\
\text { Evaluation }\end{array}$ & $\begin{array}{c}\text { Brand } \\
\text { Loyalty }\end{array}$ & $\begin{array}{c}\text { Brand } \\
\text { Relationship }\end{array}$ & Satisfaction & Trust \\
\hline $\begin{array}{l}\text { Brand Evaluation } \\
\text { Brand Loyalty }\end{array}$ & $\mathbf{0 . 8 1 0}$ & & & & \\
Brand & 0.530 & $\mathbf{0 . 7 8 1}$ & & & \\
Relationship & 0.340 & 0.444 & $\mathbf{0 . 8 6 1}$ & & \\
Satisfaction & 0.241 & 0.403 & 0.648 & $\mathbf{0 . 7 5 1}$ & \\
Trust & 0.513 & 0.375 & 0.460 & 0.376 & $\mathbf{0 . 7 4 0}$ \\
& & & & & \\
\hline
\end{tabular}

Table 3.

Composite Reliability and Cronbach's Alpha Assessment

\begin{tabular}{ccc}
\hline Variables & Cronbach's Alpha & Composite Reliability \\
\hline Brand Evaluation & 0.805 & 0.842 \\
Brand Loyalty & 0.782 & 0.791 \\
Brand Relationship & 0.779 & 0.829 \\
Satisfaction & 0.739 & 0.836 \\
Trust & 0.755 & 0.819 \\
\hline
\end{tabular}

Based on the results of the outer model assessment presented on Table 1, Table 2, and Table 3, it could be confirmed that all criteria in the outer model analysis had been fulfilled, since the value of factor loadings of each items, the value of AVE of ech variables had exceeded the cut-off value of 0.50 , and the value of cronbach's alpha and composite reliability of each variables had exceeded the cut-off value of 0.70 . 
THE IMPACT OF BRAND EVALUATION, SATISFACTION, BRAND RELATIONSHIP AND TRUST TO BRAN

LOYALITY: A CASE STUDY OF THE INDONESIAN

SMARTPHONE INDUSTRY

Furthermore, the value of AVE of each latent construct had been higher than the construct's highest squared correlation with any other latent construct in the discriminant validity analysis. Therefore, it could be concluded that all indicators and variables included on the model are valid and reliable, and the inner model analysis could be conducted afterwards.

\subsection{Inner Model Analysis and Hypotheses Testing}

Inner model analysis was conducted in order to analyze and determine the relationship between variables, analyze the mediating effect of mediating variable in this research, and to test the hypotheses proposed in this research. This research used t-value to test the hypotheses with a cut-off value of 1.96 and 5\% significance level, which means that the hypotheses will be rejected if the t-value of that hypothesis was below the cut-off value of 1.96, and supported if the t-value exceeded 1.96.

Table 4.

Path Coefficient Assessment

\begin{tabular}{|c|c|c|c|}
\hline Relationships & $\begin{array}{c}\text { T Statistics } \\
(|\mathrm{O} / \mathrm{STDEV}|)\end{array}$ & Sig. Value & Result \\
\hline $\begin{array}{c}\text { Brand Evaluation -> } \\
\text { Brand Loyalty }\end{array}$ & 2.174 & 0.014 & Significant \\
\hline $\begin{array}{c}\text { Brand Relationship -> } \\
\text { Brand Loyalty }\end{array}$ & 3.677 & 0.001 & Significant \\
\hline $\begin{array}{c}\text { Satisfaction -> Brand } \\
\text { Loyalty }\end{array}$ & 2.965 & 0.010 & Significant \\
\hline Trust $->$ Brand Loyalty & 7.492 & 0.000 & Significant \\
\hline
\end{tabular}

Table 5.

Hypotheses Testing Results

\begin{tabular}{cccc}
\hline Relationships & $\begin{array}{c}\text { T Statistics } \\
(\mid \mathbf{O} / \text { STDEV } \mid)\end{array}$ & $\begin{array}{c}\text { Sig. } \\
\text { Value }\end{array}$ & Result \\
\hline $\begin{array}{c}\text { Brand Evaluation has a positive } \\
\text { impact on Brand Loyalty }\end{array}$ & 2.174 & 0.014 & $\begin{array}{c}\text { Hypothesis } \\
\text { Supported }\end{array}$ \\
\hline $\begin{array}{c}\text { Brand Relationship has a positive } \\
\text { impact on Brand Loyalty }\end{array}$ & 3.677 & 0.001 & $\begin{array}{c}\text { Hypothesis } \\
\text { Supported }\end{array}$ \\
\hline $\begin{array}{c}\text { Satisfaction had a positive impact } \\
\text { on Brand Loyalty }\end{array}$ & 2.965 & 0.010 & $\begin{array}{c}\text { Hypothesis } \\
\text { Supported }\end{array}$ \\
\hline $\begin{array}{c}\text { Trust had a positive impact on } \\
\text { Brand Loyalty }\end{array}$ & 7.492 & 0.000 & $\begin{array}{c}\text { Hypothesis } \\
\text { Supported }\end{array}$ \\
\hline
\end{tabular}


Based on the results shown on table 4 and 5, all hypotheses were supported. The first hypothesis propose that Brand Evaluation has a positive impact on Brand Loyalty. With a t-value of 2.174 which was well above the cut-off value of $1.96(2.174$ $>1.96$ ), it could be concluded that the first hypothesis was supported in this research. The second hypothesis propose that trust has a positive impact on Brand Loyalty. With a t-value of 7.492 which was well above the cut-off value of $1.96(7.492>1.96)$, it could be concluded that the second hypothesis was also supported in this research. The third hypothesis propose that Satisfaction had a positive impact on Brand Loyalty. With a t-value of 2.965, which was well above the cut-off value of $1.96(2.965>1.96)$, it could be concluded that the third hypothesis was also supported in this research. Lastly, the fourth hypothesis propose that Brand Relationship has a positive impact on Brand Loyalty. With a t-value of 3.677, which was well above the cut-off value of 1.96 (3.677 $>1.96$ ), it could be concluded that the fourth hypothesis was also supported in this research

\subsection{Discussions}

The first hypothesis propose that Brand Evaluation has a positive effect on Brand Loyalty. In regards with the finding in this research in which this hypothesis was supported, customers tend to be loyal to brands that they evaluate higher and have a good attitude towards, and brand reputation is one of the antecedents of brand loyalty (Gilbert \& Hawlett, 2003). Velotsou (2015) state relationship or link between brand evaluation and brand loyalty exist and is positive. Furthermore, Esch et al. (2006) says that the more brand is evaluated and perceived, it can be more important predictors of current purchases and eventually lead customer to brand loyalty, so there is connection or link between brand evaluation and brand loyalty. Keller \& Lehmann (2006) state that understanding the image of the corporate and reputation impact on customer purchase is one of the key question of brand research.

The second hypothesis propose that Trust has a positive effect on Brand Loyalty. In regards with the finding in this research in which this hypothesis was supported, Hess \& Story (2005) stated that trust is important as the connector between satisfaction and personal connection and can transforming a positive transactional orientation toward a brand into enduring and close personal and commited relationship with the brand. Trust and satisfaction can combine to provide the conditions to enduring relationship between customer and brand (Hess \& Story, 2005). Moreover, Velotsou (2015) stated that brand trust has a direct and positive effect on brand loyalty. Han et al. (2008) also state that trust is one of many elements to influence on customer loyalty towards brands especially after time of crisis, so trust can enhance brand loyalty. 
THE IMPACT OF BRAND EVALUATION, SATISFACTION,

BRAND RELATIONSHIP AND TRUST TO BRAN

LOYALITY: A CASE STUDY OF THE INDONESIAN

SMARTPHONE INDUSTRY

The third hypothesis propose that Satisfaction has a positive effect on Brand Loyalty. In regards with the finding in this research in which this hypothesis was supported Velotsou (2015) state that the amount level of satisfaction derived from customer from experience using the product or services can be influence the bond developed between customer and the brand. Therefore satisfaction has a positive effect on brand loyalty (Velotsou, 2015). Satisfaction can one of the element to lead customer to repurchase, likely moderated by satisfaction, relational, and marketplace characteristics (Voss et al., 2010). According to Harris \& Goode (2004), satisfaction in various context can be translates into loyalty when customer feel of satisfaction is really high.

The fourth hypothesis propose that Brand Relationship has a positive effect on Brand Loyalty. In regards with the finding in this research in which this hypothesis was supported, it could be suggested that as the level of intensity of the relationship between customers and a brand are intensifying, it could also lead to the increase of brand loyalty toward that brand.

\section{CONCLUSIONS AND RESEARCH LIMITATIONS}

Based on the findings of this research, it could be concluded that Brand Evaluation, trust, satisfaction, and brand relationship has a positive effect on brand loyalty To improve the brand loyalty in this research, the researcher use social event like commemorate an important day, for the example aspecial day, aids day by create a special edition iphone 7 pink. Therefore brand image iphone 7 is getting better in the consumer perspective. So that can optimize brand loyalty. In regards with these findings, authors would like to suggest several strategies for companies specializing in the smartphone industry in Indonesia. First of all, in order to improve brand loyalty, it is suggested for companies to improve the security of it's product, for example, by means of adding more technologies which could improve secutiry and reduce the probability of customer's data being brached, such as the new verification features/technologies such as facial and voice recognition makes the iphone 7 more reliable. Therefore it can optimize brand loyalty. Furthermore, in order to improve the brand loyalty in this research, it is highly suggested that companies are able to the customers' satisfaction by extending the warranty of the product for a longer period of time. Therefore, if the product that was purchased by a consumer suffered from either external or internal damage within the warranty periods, it can replaced by a new one. Therefore, consumers will be more satisfied with the customer service, which could improve customers' loyalty toward the brand.

Despite the rigorous nature of this study, this research was not free of limitations. Several limitations were presented in this research. First of all, respondents 
who participated in this research were limited only to people who live in Jakarta. Therefore, it was suggested for further research to expand the geographical areas of the respondents to increase the generalizability of the results. Second, respondents in this research were limited only to people who're using Apple brand smartphone. Therefore, it is suggested that future research could select respondents who're using the other brand of smartphone. Third, this research only target total of 300 respondents, in which, only a total of 257 data from the respondents were usable. Therefore, it was highly suggested for future researchers could increase the sample size of the study to increase the generalizability of the data.

\section{REFERENCES}

Albert, N., Merunka, D., \& Valette-Florence, P. (2013). Brand passion: antecedents and consequences. Journal of Business Research. 66(7). 904-909.

Algesheimer, R., Dholakia, U. M., \& Herrmann, A. (2005). The social influence of brand community: Evidence from european car clubs. Journal of Marketing, 69(3). 19-34.

Ambler, T. (1997). How much of brand equity is explained by trust?. Management Decision, 35(4), 283-292.

Anderson, R. E., \& Srinivasan, S. S. (2003). E-satisfaction and e-loyalty: A contingency framework. Psychology \& Marketing, 20(2), 123-138.

Aurier, P., \& Séré de Lanauze, G. (2012). Impacts of perceived brand relationship orientation on attitudinal loyalty: An application to strong brands in the packaged goods sector. European Journal of Marketing, 46(11/12). 16021627.

Chaudhuri, A., \& Holbrook, M. B. (2001). The chain of effects from brand trust and brand affect to brand performance: the role of brand loyalty. Journal of marketing, 65(2). 81-93

Delgado-Ballester, E., Navarro, A., \& Sicilia, M. (2012). Revitalising brands through communication messages: the role of brand familiarity. European Journal of Marketing, 46(1/2).31-51.

Erdoğmuş, İ. E., \& Cicek, M. (2012). The impact of social media marketing onbrand loyalty. Procedia-Social and Behavioral Sciences, (58).1353-1360.

Esch, F. R., Langner, T., Schmitt, B. H., \& Geus, P. (2006). Are brands forever? How brand knowledge and relationships affect current and future purchases. Journal of Product \& Brand Management, 15(2), 98-105.

Fetscherin, M. (2014). What type of relationship do we have with loved brands? Journal of Consumer Marketing, 31 (6/7).430-440.

Ghorbani, H., \& Mousavi, S. M. (2014). The study impact of consumer personality traits on brand personality and brand loyalty (Case Study: product group of 
THE IMPACT OF BRAND EVALUATION, SATISFACTION,

BRAND RELATIONSHIP AND TRUST TO BRAN

LOYALITY: A CASE STUDY OF THE INDONESIAN

SMARTPHONE INDUSTRY

Isfahan Iran Khodro). International Journal of Academic Research in Business and Social Sciences, 4(1).371.

Gilbert, D., \& Hewlett, J. (2003). A method for the assessment of relative brand strength: a UK tour operator example. The Service Industries Journal, 23 (2), 166-182.

Gilbert, G. R., \& Veloutsou, C. (2006). A cross-industry comparison of customer satisfaction. Journal of Services Marketing, 20(5). 298-308.

Giovanis, A., \& Giovanis, A. (2016). Consumer-brand relationships' development in the mobile internet market: evidence from an extended relationship commitment paradigm. Journal of Product \& Brand Management, 25(6), 568-585.

Giovanis, A., Giovanis, A., Athanasopoulou, P., \& Athanasopoulou, P. (2017). Gen Yers' brand loyalty drivers in emerging devices. Marketing Intelligence \& Planning.

Han, X., Kwortnik Jr, R. J., \& Wang, C. (2008). Service loyalty: An integrative model and examination across service contexts. Journal of Service Research. 11 (1).22-42.

Harris, L. C., \& Goode, M. M. (2004). The four levels of loyalty and the pivotal role of trust: a study of online service dynamics. Journal of Retailing, 80 (2), 139158.

Hess, J., \& Story, J. (2005). Trust-based commitment: multidimensional consumerbrand relationships. Journal of Consumer Marketing, 22(6). 313-322.

Keller, K. L., \& Lehmann, D. R. (2006). Brands and branding: research findings and future priorities. Marketing Science, Vol. 25(6), pp.740-759.

MacDonald, S., and Headlam, N., 2011. Research-Methods-Handbook.

Malhotra, N.K. (2010). Basic marketing research an applied orientation (6 $\left.{ }^{\text {th }} \mathrm{ed}\right)$. New Jersey: Pearson Education

Mao, J. (2010). Customer brand loyalty. International Journal of Business and Management. 5(7).213.

Peng, K. F., Chen, Y., \& Wen, K. W. (2014). Brand relationship, consumption values and branded app adoption. Industrial Management \& Data Systems. 114(8).1131-1143.

Ghozali, I., and Latan, H. (2015). Konsep, teknik, dan aplikasi menggunakan program Smart Pls 3.0 untuk penelitian empiris 2th edition .

Sahin, A., Zehir, C., \& Kitapç1, H. (2011). The effects of brand experiences, trust and satisfaction on building brand loyalty; an empirical research on global brands. Procedia-Social and Behavioral Sciences .24. 1288-1301.

Taşkıı, Ç., Emel, G. G., Karadamar, A. A., \& Memiş, N. (2016). exploring the relationships among the antecedents of brand loyalty: a research on an apparel brand. IJASOS-International E-journal of Advances in Social Sciences. 2(5). 305-314.

Techinasia. (2014) Indonesia to be world's fourth-largest smartphone market by 2018. Retrieved from https://www.techinasia.com/indonesia-worlds-fourth-largestsmartphone-2018-surpass-100-million-users 
Thomson, M., MacInnis, D. J., \& Park, C. W. (2005). The ties that bind: Measuring the strength of consumers' emotional attachments to brands. Journal of Consumer Psychology, 15(1).77-91.

Too, L.H.Y., Souchon, A.L. and Thikell, P.C. (2001), "Relationship marketing in a retail setting: a dyadic exploration", Journal of Marketing Management. 17

Veloutsou, C. (2015). Brand evaluation, satisfaction and trust as predictors of brand loyalty: the mediator-moderator effect of brand relationships. Journal of Consumer Marketing, 32(6).405-421.

Voss, G. B., Godfrey, A., \& Seiders, K. (2010). How complementarity and substitution alter the customer satisfaction-repurchase link. Journal of Marketing, 74(6).111-127.

Wilson, N., (2018). The impact of service quality and brand image toward customer loyalty in the indonesian airlines industry, Jurnal Manajemen Indonesia. 18(3), 222-234.

Wilson, N., Theodorus, E., and Tan, P. (2017). Analysis of factors influencing green purchase behavior: a case study of the cosmetics industry in indonesia, Jurnal Muara Ilmu Sosial, Humaniora, dan Seni, 2 (1).453-464.

Wilson, N., and Keni, K. (2018). Pengaruh website design quality dan kualitas jasa terhadap repurchase intention: variabel trust sebagai variabel mediasi, Jurnal Manajemen dan Pemasaran Jasa, 11(2). 291-310.

Wood, L. (2000). Brands and brand equity: definition and management. Management Decision, 38(9).662-669.

Xingyuan, W., Li, F., \& Wei, Y. (2010). How do they really help? An empirical study of the role of different information sources in building brand trust. Journal of Global Marketing, 23(3).243-252.

Zhou, Z., Zhang, Q., Su, C., \& Zhou, N. (2012). How do brand communities generate brand relationships? intermediate mechanisms. Journal of Business Research. 65(7).890-895. 